\title{
Integrating Life Skills into Sport Club Activity
}

\author{
Isna Daniyati Nursasih*, Amung Ma'mun, Agus Mahendra, Risma Risma, Rita Rohmanasari \\ Sekolah Pascasarjana \\ Universitas Pendidikan Indonesia \\ Bandung, Indonesia \\ *isnadn@student.upi.edu
}

\begin{abstract}
This study aims to determine the effect of life skills development programs into sports clubs by integrating life skills components into exercise programs compared to sports clubs and sample groups not involved in sport club activities. The instrument used is Life Skills Scale for Sport questionnaire. Integration is only done $25 \%$ of the overall training program provided by the trainer. Data collection with pre-test and posttest of all sample groups. Data is processed by $t$ test, after the data is processed the results show that, (1) Integration of life skills into sports club with the discussion model and the exposure of material by the researchers showed a very uphill graph, (2) Compared with those who did not get life skills the difference was so significant with $t$ count of 5.59. (3) Similarly, compared with that at all not involved in sports club activities very significant difference is obtained $t \mathbf{1 0 . 6 3}$, in addition, the involvement of samples in activities at sports clubs is far away. After analyzing the data, the result shows that integration in the sports club contributes greatly to the improvement of life skills. Activities in sports clubs make an outstanding contribution to the development of life skills.
\end{abstract}

Keywords—sport club; life skills

\section{INTRODUCTION}

Hodge and Danish, suggests that life skills are defined as the skills needed to deal with the demands and challenges of everyday life [1]. In this case the intended skills are life skills. According to the definition of the World Health Organization (WHO), life skills are the ability to behave in an adaptive and positive manner that enables a person to effectively solve their daily needs and challenges. In line with the opinion of Gould and Carson which states that to succeed in a competitive and constantly changing global economy, the younger generation must develop life skills [1]. The interest in developing life skills through sports, especially in children and adolescents is clearly seen today. Most youth sports organizations today are run in a modern style that prioritizes development in the socialemotional aspects [2]. This positive youth development encourages positive psychosocial development by increasing emotional, behavioral, social and cognitive quality aspects in children and adolescents through social and environmental interactions [3].

Adolescents choose their involvement in sports, according to their interests both in sports clubs or in extracurricular activities. Those who choose to be involved in sports clubs, for the professionalization of sports that are followed by teenagers, are characterized by the specialization of sports at the beginning of the training and intensive training throughout the year [4]. This tendency to increase specialization in sports often directs teenagers to participate in sports clubs in addition to the sport in their schools, this is also expected to result in an increase in the volume of competition throughout the year [5]. In particular, the theory of self-determination [6] seems to be a theory that can be used as a reference to investigate the mechanism by which teens develop their life skills through sports. Sports is one of the activities that is often done during leisure time which is most popular among teenagers, sports are often held in the form of sports clubs or extracurricular activities in schools [7]. As the most popular recreational activity for teenagers, sports have been proposed as an ideal condition for the development of life skills [8]. The purpose of developing life skills is to provide insight for young people in accordance with what is needed in everyday life.

\section{METHOD}

\section{A. Participants}

The population in this study were teenagers who participated in sports clubs in Ciamis Regency. The sample in this study were children aged 13-15 years who participated in badminton sports clubs in Ciamis Regency. Samples that are given life skills content are SSB Fortuna members aged 13-15 as many as 25 people, samples that are not given life skills are members of SSB Bonansa with ages 13-15 as many as 23 people and samples who do not attend sports clubs are junior high school students Manarul Huda with a total sample of 28 people

\section{B. Procedures}

The use of methods in research is tailored to the problems and objectives to be studied. Referring to this study, the research method that the writer chose and determined was the experimental method. The research was conducted by pretestposttest control group design.

\section{Instruments}

In this study, data was collected using a questionnaire or Life Skills Scale for Sport questionnaire (LSSS) developed by Cronin \& Allen [1]. The test is done only once can provide an assessment of the ability of students in variables that the author carefully. LSSS instruments are intended for sports participants of adolescents aged between 11 to 21 years. The LSSS instrument contains eight life skills with 47 closed question 
items. The scale range used is a 5-point scale, which is 1 (not at all) to 5 (very much).

\section{RESULTS AND DISCUSSION}

The purpose of data analysis is to test the hypothesis proposed in this study that is to see whether or not the impact is given from the life skills integration program to the training program. Based on the data that has been collected from the results of the research, the next step is to process and analyze the data.

\section{A. $\quad$ test}

The $t$ test is used to test the variance analysis of the average difference from data groups that are normally distributed. The results of the calculation can be seen in table 1 .

TABLE I. HyPOTHESIS TEST BASED ON INTEGRATING LIFE SKILLS

\begin{tabular}{|c|c|c|c|c|c|c|c|}
\hline \multirow{2}{*}{$\begin{array}{c}\text { Tes } \\
\mathbf{t} \\
\text { res } \\
\text { ult }\end{array}$} & \multirow[b]{2}{*}{ Cub type } & \multirow[b]{2}{*}{$\mathbf{N}$} & \multirow[b]{2}{*}{$X \pm \mathrm{SD}$} & \multicolumn{2}{|c|}{ Uji t } & \multirow{2}{*}{$\begin{array}{c}\text { inf } \\
\text { or } \\
\text { ma } \\
\text { tio } \\
\text { n }\end{array}$} & \multirow{2}{*}{$\begin{array}{c}\text { Perce } \\
\text { nt } \\
\text { differ } \\
\text { ent }\end{array}$} \\
\hline & & & & $\begin{array}{c}t \\
\text { hitun } \\
g\end{array}$ & $\begin{array}{c}t \\
\text { tabe } \\
l\end{array}$ & & \\
\hline \multirow{2}{*}{$\begin{array}{c}\text { Lif } \\
\text { e } \\
\text { Skil } \\
\text { ls }\end{array}$} & $\begin{array}{c}\text { With } \\
\text { integrating } \\
\text { life skills }\end{array}$ & $\begin{array}{l}2 \\
5\end{array}$ & $\begin{array}{l}194,12 \pm \\
14,08\end{array}$ & \multirow{2}{*}{2,48} & \multirow{2}{*}{$\begin{array}{l}1,7 \\
08\end{array}$} & \multirow{2}{*}{$\begin{array}{l}\text { Sig } \\
\text { nifi } \\
\text { kan }\end{array}$} & \multirow{2}{*}{$8,28 \%$} \\
\hline & $\begin{array}{c}\text { Without } \\
\text { integrating } \\
\text { life siklls }\end{array}$ & $\begin{array}{l}2 \\
3\end{array}$ & $\begin{array}{l}179,26 \pm \\
21,87\end{array}$ & & & & \\
\hline
\end{tabular}

It can be seen that the significance value in the group is based on the life skills content, because the value of the group t count based on the given life skills content is greater than $t$ table (1.708) then $\mathrm{H} 0$ is accepted thus there is a significant difference in influence for children who participate in sports club activities given the life skills content compared to those not given. This, explains that there is a difference in the effect between the charge in sports club activities.

The results of the calculation of the t-test on the average difference test based on the life skills charge with those who do not join the sports club are presented in table 2 .

TABLE II. HYPOTHESIS TEST BASED ON THE INTEGRATING OF LIFE SKILLS CONTENT AND PARTICIPATION/ IN SPORTS CLUBS

\begin{tabular}{|c|c|c|c|c|c|c|c|}
\hline \multirow{2}{*}{$\begin{array}{c}\text { Hasi } \\
1 \\
\text { Tes }\end{array}$} & \multirow{2}{*}{$\begin{array}{c}\text { Aktivitas } \\
\text { dalam } \\
\text { Klub }\end{array}$} & \multirow{2}{*}{$\mathbf{N}$} & \multirow{2}{*}{$\bar{X} \pm \mathrm{SD}$} & \multicolumn{2}{|c|}{ Uji t } & \multirow{2}{*}{ Ket } & \multirow{2}{*}{$\begin{array}{c}\text { Per } \\
\text { sen } \\
\text { bed } \\
\text { a }\end{array}$} \\
\hline & & & & $\begin{array}{c}t \\
\text { hitung }\end{array}$ & $\begin{array}{c}t \\
\text { tabe } \\
l\end{array}$ & & \\
\hline \multirow{2}{*}{$\begin{array}{c}\text { Life } \\
\text { Skill } \\
\text { s }\end{array}$} & $\begin{array}{c}\text { Without } \\
\text { integrating } \\
\text { life skills }\end{array}$ & $\begin{array}{l}2 \\
5\end{array}$ & $\begin{array}{l}179,26 \quad \pm \\
21,87\end{array}$ & \multirow{2}{*}{5,59} & \multirow{2}{*}{$\begin{array}{l}1,7 \\
13\end{array}$} & $\begin{array}{l}\text { Sig } \\
\text { nififi }\end{array}$ & \multirow{2}{*}{$\begin{array}{l}20, \\
71 \\
\%\end{array}$} \\
\hline & Non club & $\begin{array}{l}2 \\
8 \\
\end{array}$ & $\begin{array}{ll}148,50 \quad \pm \\
17,18\end{array}$ & & & kan & \\
\hline
\end{tabular}

From table 2 it is known that the value of $t$ arithmetic in groups based on charge and participation in sports clubs 5.59 is greater than 1.713 then $\mathrm{H} 0$ is rejected and $\mathrm{H} 1$ is accepted thus there is a significant difference in influence for children who take part in activities in sports clubs with no charge life skills. This, explains that there is a difference in influence between children who take part in activities in sports clubs that are not given life skills content compared to those who do not engage in sports clubs to improve life skills.

The results of the calculation of the $t$ test, the average difference test based on the participation and giving of LS load are presented in table 3 below:

TABLE III. HYPOTHESIS TEST BASED ON PARTICIPATION AND INTEGRATING LIFE SKILLS

\begin{tabular}{|c|c|c|c|c|c|c|c|}
\hline \multirow{2}{*}{$\begin{array}{c}\text { Tes } \\
\text { t } \\
\text { res } \\
\text { kut }\end{array}$} & \multirow{2}{*}{$\begin{array}{c}\text { Ckub } \\
\text { activities }\end{array}$} & \multirow[b]{2}{*}{$\mathbf{N}$} & \multirow[b]{2}{*}{$X \pm \mathbf{S D}$} & \multicolumn{2}{|c|}{ Uji t } & \multirow{2}{*}{$\begin{array}{l}\text { info } \\
\text { rm } \\
\text { atio } \\
\mathbf{n}\end{array}$} & \multirow{2}{*}{$\begin{array}{c}\text { Perce } \\
\text { nt } \\
\text { differ } \\
\text { ent }\end{array}$} \\
\hline & & & & $\begin{array}{c}t \\
\text { hitun } \\
g\end{array}$ & $\begin{array}{c}t \\
t a b e \\
l\end{array}$ & & \\
\hline \multirow{2}{*}{$\begin{array}{c}\text { Life } \\
\text { Skil } \\
\text { ls }\end{array}$} & $\begin{array}{c}\text { With } \\
\text { integrating } \\
\text { life skills }\end{array}$ & $\begin{array}{l}2 \\
3\end{array}$ & $\begin{array}{l}194,12 \pm \\
14,08\end{array}$ & \multirow[t]{2}{*}{10,63} & \multirow{2}{*}{$\begin{array}{l}1,70 \\
8\end{array}$} & \multirow{2}{*}{$\begin{array}{l}\text { Sig } \\
\text { nifi } \\
\text { kan }\end{array}$} & \multirow{2}{*}{$\begin{array}{l}30,72 \\
\%\end{array}$} \\
\hline & No club & $\begin{array}{l}2 \\
8\end{array}$ & $\begin{array}{l}148,50 \quad \pm \\
17,18\end{array}$ & & & & \\
\hline
\end{tabular}

From table 3 it is known that the value of $t$ arithmetic on groups based on the activity and content of life skills in sports clubs 10.63 , because the value of this group's t count is greater than $\mathrm{t}$ table (1.708) then $\mathrm{H} 0$ is accepted thus there are differences in meaningful influence for children given the content of life skills in sports clubs to increase life skills. This, explains that there is a significant difference in the effect of activities in sports clubs that are given life skills content compared to those who do not engage in sports club activities to increase life skills.

The first hypothesis looks at the differences that occur from activities in sports clubs that are given a life skills charge compared to activities in sports clubs that are not given a life skills charge for improving life skills for sports club participants. There are significant differences in the results of the hypothesis test obtained, that activities in sports clubs that are given a life skills charge will have a better influence on life skills improvement compared to activities in sports clubs that are not given life skills. Judging from the different tests the two groups obtained a value of $8.28 \%$. This value does not show such a big difference, but it can be seen that children who carry out activities in sports clubs even though they are not given a child's life skills content have been able to show that the 8 components in life skills contained in the test instrument have had a good influence for them. Indirectly the activities that children do in sports clubs have provided them with these life skills.

The second hypothesis sees significant differences in activities in sports clubs that are not given a life skills charge compared to those who do not engage in sports clubs on improving life skills. Based on the calculations made from the two groups compared, there are significant differences in the results of the hypothesis test obtained, that activities in sports clubs that are not given a life skills charge give a better influence on life skills improvement compared to those who do not engage in club activities. Judging from the different tests of the two groups obtained a value of $20.71 \%$. This value shows a big difference, it can be seen that children who carry out activities in sports clubs even though they are not given a life skills load indirectly the activities that children do in these 
sports clubs have provided them with these life skills. In contrast to children who do not participate in sports clubs, it does not really show that children know about life skills. Although in other activities outside the sports club the components of life fatigue can children get, but activities in sports clubs still provide more experience and equip them about these life skills.

The third hypothesis looks at the differences that occur from activities in sports clubs that are given a life skills charge compared to those who do not engage in sports clubs on improving life skills. Based on the calculations made from the two groups compared there are significant differences in the results of the hypothesis test obtained, activities in sports clubs that are given life skills content provide a better influence on life skills improvement compared to those who do not engage in sports clubs. Judging from the different tests both groups obtained a value of $30.72 \%$. This value shows a big difference, it can be seen that children who carry out activities in sports clubs with a life skills charge give a big influence on improving children's life skills. Children's life skills develop in line with the provision of life skills. In contrast to children who do not participate in sports clubs, it does not really show that children know about life skills.

In conducting research in groups that were given life skills content, researchers only integrated the life skills load of $25 \%$ from the overall sports club coach program. A large number of life skills components can be learned through participation in sports, as explained in an article that discusses the development of the Canada Golf youth program. This research reviews the development of life skills in adolescence by creating the most common list of life skills identified as being developed through sports. This list of life skills components developed contains 13 life skills [9]. In life skills integration research conducted, using 8 components of life skills with 8 meetings, each meeting discussed one component of life skills. Giving material with simulation or demonstration and lecture material [10].

\section{CONCLUSION}

The components in life skills are integrated into the training programs that are exceptional in the development of children, not only in the field of sports but in a different environment from where children live. Unconsciously in sports activities, children have agreed to the components collected. Sports are complex activities. After being given the communication component, life skills into the usual training program, they start talking about them not only for sports, but more than that, think positively and be useful to save their lives. Just by involving in sports club activities alone has given a different improvement to improving life skills, supported by programs that are supported by life skills will greatly make an interesting difference about children who are not involved in sports at all at sports clubs.

\section{REFERENCES}

[1] L.D. Cronin, and J. Allen, "Development and initial validation of the Life Skills Scale for Sport". Psychology of Sport and Exercise, vol. 28, pp. 105-119, 2017.

[2] D. Gould, and S. Carson, "Life skills development through sport: current status and future directions". International Review of Sport and Exercise Psychology, 1(1), 58-78, 2008.

[3] J. Johnston, C. Harwood, and A.M. Minniti, "Positive Youth Development in Swimming: Clarification and Consensus of Key Psychosocial Assets". Journal of Applied Sport Psychology, vol. 25(4), pp. 392-411, 2013.

[4] S. Rangeon, W. Gilbert, and M. Bruner, Journal of Coaching Education, vol. 5(1), pp. 83-113, 2012

[5] E.G. Post, D.R. Bell, S.M. Trigsted, A.Y. Pfaller, S.J. Hetzel, M.A. Brooks, and T.A. McGuine, "Association of Competition Volume, Club Sports, and Sport Specialization With Sex and Lower Extremity Injury History in High School Athletes". Sports Health, vol. 9(6), pp. 518-523, 2017.

[6] R.M. Ryan, and E.L. Deci, "Self-determination theory and the facilitation of intrinsic motivation, social development, and well-being". The American Psychologist, 55(1), 68-78, 2000.

[7] S. Geidne, M. Quennerstedt, and C. Eriksson, "The youth sports club as a health-promoting setting: An integrative review of research". Scandinavian Journal of Public Health, vol. 41(3), pp. 269-283, 2013.

[8] D.M. Hansen, and R.W. Larson, "Amplifiers of developmental and negative experiences in organized activities: Dosage, motivation, lead roles, and adult-youth ratios". Journal of Applied Developmental Psychology, vol. 28(4), pp. 360-374, 2007.

[9] K. Kendellen, M. Camiré, C.N. Bean, and T. Forneris, Integrating life skills into Golf Canada â€TM $s$ youth programs: Insights into a successful research to practice partnership, 704(September), 2006.

[10] S.J.D. Male, and B.D., "Toward An Understanding of the". Academy of Management Review, vol. 3(2), pp. 213-226, 1998. 